\title{
Pelanggaran Hak Paten Aplikasi Facetime
}

\author{
Sigit Toni Nurcahyo \\ 155100072 \\ Fakultas Komputer, 448757158 \\ Sigittoninurcahyo.student@umitra.ac.id
}

\begin{abstract}
FaceTime adalah nama aplikasi panggilan video (video call) buatan Apple yang mendukung panggilan audio-only dan video di antara perangkat yang kompatibel. FaceTime pada awalnya diperkenalkan oleh Apple di iPhone 4 pada tahun 2010, namun sekarang support pada sejumlah perangkat Apple, termasuk iPad, iPod touch, dan Mac.

Perusahaan komunikasi VirnetX asal negeri paman sam ini menggugat Apple ke pengadilan. VirnetX Holding Corp menuntut Apple atas hak paten yang terdapat pada aplikasi FaceTime, bukan aplikasinya, namun paten keamanan yang terdapat pada aplikasi tersebut yang di permasalahkan.
\end{abstract}

VirnetX sendiri merupakan perusahaan teknologi dan komunikasi yang didirikan oleh sekelompok karyawan yang berasal dari Science Applications International Corp (SAIC). Perusahaan ini pun mengembangkan teknologi keamanan untuk agen-agen federal di Amerika Serikat.

VirnetX telah melayangkan gugatan ke pengadilan di Amerika Serikat, tepatnya di Washington DC. Tidak hanya itu, perusahaan tersebut menuntut Apple untuk membayar sekitar $\$ 302,4$ juta atau berkisar 3,92 triliun Rupiah.

Kata Kunci : Aplikasi FaceTime, Apple inc, dan VirnetX. 


\section{A. INTRODUCTION}

Salah satu fitur unggulan Apple yaitu Facetime, pada perangkat iOS dan Macintosh. Layaknya panggilan video pada umumnya, Apple lebih menawarkan jaminan keamanan pada saat berkomunikasi.

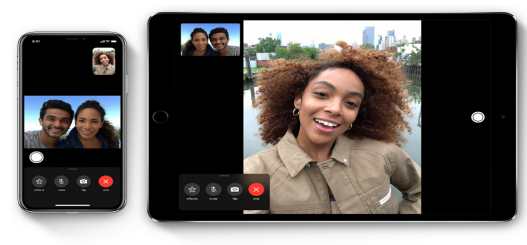

FaceTime adalah nama aplikasi panggilan video (video call) buatan Apple yang mendukung panggilan audio-only dan video di antara perangkat yang kompatibel. FaceTime pada awalnya diperkenalkan oleh Apple di iPhone 4 pada tahun 2010, namun sekarang support pada sejumlah perangkat Apple, termasuk iPad, iPod touch, dan Mac.

VirnetX Holding Corp menuntut Apple atas hak paten yang terdapat pada aplikasi FaceTime, Bukan aplikasinya, namun paten keamanan yang terdapat pada aplikasi tersebut yang dipermasalahkan.

Bahkan VirnetX telah melayangkan gugatan ke pengadilan di Amerika Serikat, tepatnya di
Washington DC. Tidak hanya itu, perusahaan tersebut menuntut Apple untuk membayar sekitar \$302,4 juta atau berkisar 3,92 triliun Rupiah.

VirnetX sendiri merupakan perusahaan teknologi dan komunikasi yang didirikan oleh sekelompok karyawan yang berasal dari Science Applications International Corp (SAIC). Perusahaan ini pun mengembangkan teknologi keamanan untuk agen-agen federal di Amerika Serikat. Namun kabarnya akhir-akhir ini pendapatan VirnetX berasal dari hak paten yang mereka miliki. Perusahaan ini pun pernah berhadapan dengan perusahaan ternama seperti Microsoft an Cisco, yang berakhir juga di meja hijau.

Bukan kali pertama VirnetX berseteru dengan Apple, sebelumnya di tahun 2010 VernetX mengugat Apple atas empat hak paten. Kasus dimenangkan oleh VernetX dan Apple akhirnya membayar $\$ 368,2$ juta atau berkisar 4,8 triliun Rupiah. Lalu Apple harus berhadapan lagi dengan VirnetX pada bulan Juli lalu, terkait paten pada aplikasi iMessage dan menuntut Apple dengan $\$ 625,6$ juta. Namun hakim masih mempertimbangkan kasus tersebut. 


\section{B. CONCLUSION}

Dalam kasus diatas pihak Apple melanggar hak paten milik VirnetX Holding Corp. Yang di permasalahkan pihak VirbetX bukan aplikasi yang dibuat pihak Apple dalam hal ini aplikasi Facetime yang tidak asing lagi para pengguna Apple, melainkan fitur keamanan yang ditawarkan dalam aplikasi Facetime tersebut. Hal ini tentu merugikan pihak VirnetX atas penemuan yang dibuatnya yang kemudian digunakan tanpa izin oleh pihak Apple, dari kasus diatas pun dikatakan pihak VirnetX menuntut ganti rugi dengan nominal yang cukup besar. Hal ini tentu bukan hanya merugikan pihak VirnetX saja karena penemuannya digunakan tanpa izin tetapi kerugian financial pula yang dirasakan oleh pihak Apple. Seharusnya sebuah perusahaan besar harus lebih berhati-hati dan jeli atas penemuan yang akan dipubikasikan ke masyarakat luas, serta seharusnya mempertimbangkan untung dan rugi dari sikap yang diambil agar dikemudian hari tidak menimbukan permasalahan oleh pihak manapun.

\section{ACKNOWLEDGEMENT}

University Of Indonesia
University of Mitra Indonesia
Telkom University
University Of Mellbourne
Saitama University

\section{REFERENCE (Based ISO 690)}

[1]

A. S. Putra And O. M. Febriani,
“Knowledge Management
Online Application In Pdam
Lampung Province," In
Prosiding International
Conference On Information
Technology And Business
(Icitb), 2018, Pp. 181-187.

[2] A. S. Putra, O. M. Febriani, And B. Bachry, "Implementasi Genetic Fuzzy System Untuk Mengidentifikasi Hasil Curian Kendaraan Bermotor Di Polda Lampung," J. Sist. Inf. Dan Manaj. Basis Data, Vol. 1, No. 1, Pp. 21-30, 2018.

[3] O. M. Febriani And A. S. Putra, "Sistem Informasi Monitoring Inventori Barang Pada Balai Riset Standardisasi Industri Bandar Lampung," J. Inform., Vol. 13, No. 1, Pp. 90-98, 2014.

[4] Putra, Arie Setya. "2018 Artikel Struktur Data, Audit Dan Jaringan Komputer." (2018).

[5] Putra, A. S. (2018, July 17). Paperplain Fundamental Create Application With Borland Delphi 7.0 University Of Mitra Indonesia. Retrieved From Osf.lo/Pbrn9. 


\section{E. REFERENCE (Based APA)}

Putra, A. S., Aryanti, D. R., \& Hartati, I. (2018, November). Metode SAW (Simple Additive Weighting) sebagai Sistem Pendukung Keputusan Guru Berprestasi (Studi Kasus: SMK Global Surya). In Prosiding Seminar Nasional Darmajaya (Vol. 1, No. 1, pp. 85-97).

Sari, D. P., Febriani, O. M., \& Putra, A. S. (2018, November). Perancangan Sistem Informasi SDM Berprestasi pada SD Global Surya. In Prosiding Seminar Nasional Darmajaya (Vol. 1, No. 1, pp. 289-294).

Putra, A. S. (2018). Paperplain: Execution Fundamental Create Application With Borland Delphi 7.0 University Of Mitra Indonesia.

Putra, A. S., Sukri, H., \& Zuhri, K. Sistem Monitoring Realtime Jaringan Irigasi Desa (JIDES) Dengan Konsep Jaringan Sensor Nirkabel. IJEIS (Indonesian Journal of Electronics and Instrumentation Systems), 8(2), 221-232.

Darmawan, A., Yuliawati, D., Marcella, O., \& Firmandala, R. (2016). Sistem Absensi dan Pelaporan Berbasis Fingerprint dan SMS Gateway. EXPLORE, 7(1).

Febriani, O. M., Wahyuni, T., \& Yusuf, S. (2017). DESIGN OF WEBSITE-BASED INFORMATION SYSTEM FOR EDOCUMENT ADMINISTRASI IN THE COMMUNITY SERVICE UNIT (A
Case Study at Rajabasa District). INTERNATIONAL JOURNAL OF COMPUTERS \& TECHNOLOGY, 16(7), 7010-7020.

Febriani, O. M., \& Wahyuni, T. (2017, October). PERANCANGAN SISTEM E-DOCUMENT ADMINISTRASI LOGBOOK PENELITIAN PADA UNIT LAYANAN DI BANDAR LAMPUNG. In Prosiding Seminar Nasional Darmajaya (Vol. 1, No. 1, pp. 187194).

Febriani, O. M., \& Permadi, A. B. (2017). Implementasi Sistem Aplikasi Data Bimbingan dan Pelanggaran Siswa pada Sekolah Menengah Atas di Lampung Tengah dengan Metode Analisis dan Desain Sistem Terdistribusi (SSAD). EXPERT, 7(1).

Febriani, O. M., \& Ambarwati, L. (2015). PERANCANGAN APLIKASI PENGOLAHAN DATA PENJUALAN UKM KELANTING KHAS TELO DESA SIDOHARJO KECAMATAN JATI AGUNG KABUPATEN LAMPUNG SELATAN. Jurnal Teknologi Informasi dan Bisnis Pengabdian Masyarakat Darmajaya, 1(1), 77-95.

Febriani, O. M. (2015). Rancang Bangun Aplikasi Ecommercemenggunakan Freewebstore pada UKM Kelanting di Desa Sidoharjo Lampung Selatan. Prosiding Sembistek 2014, 1(02), 446-458. 